\title{
ON THE TRANSMISSION OF ANTIBODIES FROM MOTHERS TO THEIR OFFSPRINGS IN EXPERIMENTAL TYPHUS FEVER, EXPERIMENTS IN ALBINO RATS AND GUINEA PIGS
}

\author{
KEIICHIRO JO \\ The National Institute of Health, Tokyo, Japan
}

(Received: December 6th, 1952)

It has been well known that the maternal immunity is transmitted to the offsprings. For example, newborns of 3 to 6 months old, as a rule are seldome attacked by scarlet fever, small pox, chicken pox or measles. On the contrary, if mothers do not have the immunity, their newborns may often be attacked by the above diseases.

Recent advances in virology and rickettsiology have made the objective and quantitative analysis of antibodies in viral and rickettsial diseases possible.

The neutralizing antibodies in Influenza (Rickard(1), Tsurumi(2)), in Japanese B Encephlitis (Segawa ${ }^{(3)}$, Mitamura(4) and Kitaoka(5) ${ }^{(5)}$, in Poliomyelitis (Aycock(6), Kitaoka(7)); the protective substances in yellow fever (Soper ${ }^{(8)}$, in Coxackie virus (Melnick(9)); the complement-fixing antibodies in Lymphogranuloma venereum (Levine(10)); the haemagglutination inhibiting antibodies in swine influenza Shope No. 15 (Young(11) ) etc. were demonstrated to be transferred from the mother to the offsprings.

Here, the transmissions of the antibodies from the mother to the offsprings were studied in experimental murine and epidemic typhus fever, using albino rats and guinea pigs. Besides, the way through which the maternal antibodies are transmitted to the offsprings was carefully investigated. Highly specific and easily determinable complement fixing antibodies (C. F. antibodies) were selected as the indicater.

Material and Method:

Animals used: Adult female albino rats weighing $150-200 \mathrm{~g}$, and adult female guinea pigs weighing 500-700 $\mathrm{g}$.

Method of immunization: 1) Active immunization with live reckettsiae; 1 cc of a $5-10 \%$ R. prowazeki (Breinl strain) or R. typhi (Wilmington strain) infected yolk sac emulsion was injected intraperitoneally. 2) Active immunization with killed rickettsiae or vaccine; commercial epidemic typhus vaccine was injected intraperitoneally or subcutaneously in divided dosis of 1-5 cc. 3) Passive immunization with specific serum; the rabbit and guinea pig sera specially immunized against epidemic and murine typhus were inoculated subcutaneously or intraperitoneally.

Method of bleeding from the mothers 'and newborns: Bleeding from the mothers was performed by cardial puncture with or without anaesthesia of 
ethyl ether. Bleeding from newborn guinea pigs was found not so difficult but from newborn rats sometimes difficult, and the amounts of blood obtained were often insufficient to perform the C. F. T., so that the blood specimens from more than 2 rats were pooled. Bleeding from newborn rats was practised by opening the thorax and puncturing the heart and test-tubes of smaller calibre, $2-3 \mathrm{~mm}$ in diameter were used for centrifugation to collect serum specimens.

Method of bleeding from the foetus of guinea pig and collecting its amniotic fluid: Foetus was taken out by laparotomy. First, the amniotic fluid was collected taking care not to mix the mother's blood and the foetus was bled by opening the thorax and puncturing the heart.

Method of C. F. T. and the reading of its results: The method of C. F. T. and the reading of its results are as usual(12). As antigens, epidemic typhus (Breinl strain) and murine typhus (Wilmington strain) were used. Testing of the serum samples was done with the initial dilution 1:10. For securing the accuracy in reading the results, sera of one series of experiments were tested simultaneously by taking the final serum sample and known positive and negative control sera were used. Serum specimens were preserved in dryice box, as a rule, to avoid the development of anti-complementary effect.

A. Results obtained in albino rats

Preliminary experiment: The pattern of C. F. antibodies in rats inoculated with $1 \mathrm{cc}$ of $5 \% R$. typhi yolk sac emulsion was as shown in Fig. 1. The

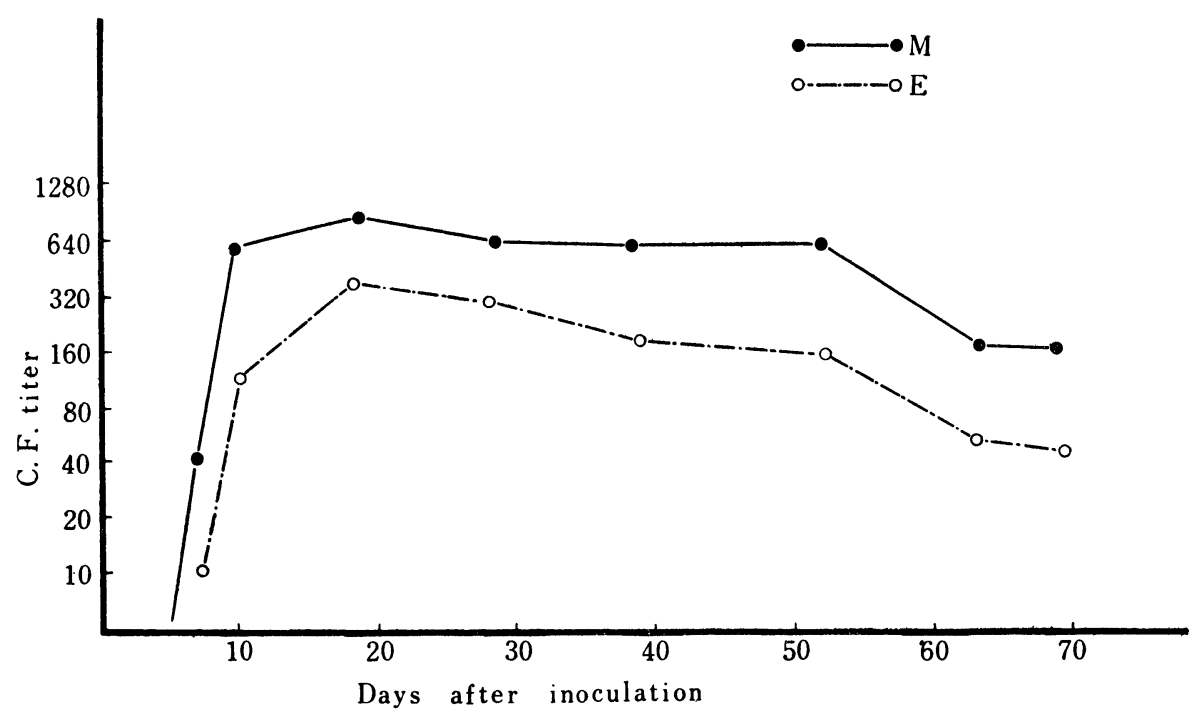

Fig. 1. C.F. antibody pattern in albino rats

C. F. antibodies for murine typhus antigen (M) increased quickly following the inoculation and showed the titre of 1:640-1:1280 on the 10th day. The animals maintained the high titre of 1:640 for 50 days and the titre of 1:160 
remained for a longer period thenceforth. The remarkable cross reaction against epidemic typhus antigen (E) was demonstrated. From the above results, the following experiments (Exp. 1-Exp. 3) of active immunization with live $R$. typhi were carried out.

Experiment 1. The C. F. antibodies in the newborns delivered by activelyimmunized mothers and nursed by the same mothers (Table 1): $R$. typhi

Table 1

\begin{tabular}{|c|c|c|c|c|c|c|c|c|c|c|c|c|}
\hline \multirow{3}{*}{ 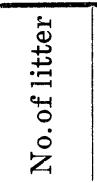 } & \multirow{3}{*}{ 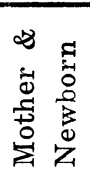 } & \multicolumn{9}{|c|}{ C.F. titer } & \multirow{3}{*}{ 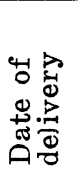 } & \multirow{3}{*}{ 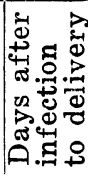 } \\
\hline & & \multicolumn{9}{|c|}{ Weeks after delivery to bleeding } & & \\
\hline & & \begin{tabular}{|} 
Imme- \\
diately
\end{tabular} & 1 & 2 & 3 & 4 & 5 & 6 & 7 & 8 & & \\
\hline \multirow[b]{2}{*}{ R 7} & M & $\mid \begin{array}{rr}\mathrm{E} & 320 \\
\mathrm{M} & 1280\end{array}$ & & $\begin{array}{|ll|}\mathrm{E} & 320 \\
\mathrm{M} & 640\end{array}$ & & $\begin{array}{ll}\mathrm{F} & 320 \\
\mathrm{M} & 640\end{array}$ & & $\mid \begin{array}{ll}\mathrm{E} & 160 \\
\mathrm{M} & 640\end{array}$ & & $\mid \begin{array}{rr}\mathrm{E} & 40 \\
\mathrm{M} & 160\end{array}$ & $12, \mathrm{XI}$ & \multirow{2}{*}{12} \\
\hline & $N$ & $\begin{array}{c}\text { M 40 } \\
*(1,2)\end{array}$ & $\begin{array}{c}\text { M } 320 \\
(3)\end{array}$ & $\begin{array}{c}\mathrm{M} 320 \\
(4)\end{array}$ & & $\left|\begin{array}{c}M \\
(5)\end{array}\right|$ & & $\mid \begin{array}{c}\mathrm{M} 40 \\
(6)\end{array}$ & & $\mid \begin{array}{l}\left(\frac{-}{(6)}\right) \\
\end{array}$ & 51 & \\
\hline \multirow[b]{2}{*}{$\mathrm{R} 15$} & M & $\begin{array}{l}\text { E } 160 \\
\text { M } 640\end{array}$ & & \multicolumn{3}{|c|}{$\left|\begin{array}{lr}\mathrm{E} & 40 \\
\mathrm{M} & 160\end{array}\right|$} & & & & & \multirow[b]{2}{*}{$\begin{array}{c}24 / \mathrm{I} \\
' 52\end{array}$} & \multirow[b]{2}{*}{58} \\
\hline & $\mathrm{N}$ & $\begin{array}{c}\mathrm{E} 10 \\
\mathrm{M} 40 \\
(1,2)\end{array}$ & $\left|\begin{array}{lr}E & 40 \\
M & 160 \\
(5)\end{array}\right|$ & 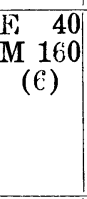 & $\begin{array}{c}\mathrm{E} 10 \\
\mathrm{M} 40 \\
(7) \\
\mathrm{E} 10 \\
\mathrm{M} 80 \\
(8)\end{array}$ & $\left|\begin{array}{rr}\mathrm{E} & 0 \\
\mathrm{M} & 40 \\
(6,8)\end{array}\right|$ & $\begin{array}{cc}\mathrm{E} & 0 \\
\mathrm{M} & 20 \\
(6) \\
\mathrm{E} & 0 \\
\mathrm{M} & 20 \\
(7)\end{array}$ & $\begin{array}{l}(-) \\
(6) \\
(-) \\
(8)\end{array}$ & & & & \\
\hline \multirow{3}{*}{ R107 } & M & $\begin{array}{lr}\mathrm{E} & 10 \\
\mathrm{M} & 160\end{array}$ & & & & & & & & & \multirow{3}{*}{$\begin{array}{c}25 / \mathrm{I} \\
' 52\end{array}$} & \multirow{3}{*}{86} \\
\hline & \multirow{2}{*}{$\mathrm{N}$} & $\begin{array}{c}\mathrm{E} 40 \\
\mathrm{M} 10 \\
(1,2)\end{array}$ & & & $\begin{array}{ll}\mathrm{E} & 0 \\
\mathrm{M} & 80 \\
(3,4)\end{array}$ & $\left|\begin{array}{cc}\mathrm{E} & 20 \\
\mathrm{M} & 80 \\
(5)\end{array}\right|$ & $\begin{array}{lr}\mathrm{E} & 0 \\
\mathrm{M} & 40 \\
(7,8)\end{array}$ & $\left|\begin{array}{cr}\mathrm{E} & 0 \\
\mathrm{M} & 10 \\
(5)\end{array}\right|$ & $\begin{array}{c}(-) \\
(5)\end{array}$ & & & \\
\hline & & & & & & $\left|\begin{array}{cc}\mathrm{E} & 10 \\
\mathrm{M} & 80 \\
(6)\end{array}\right|$ & & $\left|\begin{array}{cr}\mathrm{E} & 0 \\
\mathrm{M} & 10 \\
(7)\end{array}\right|$ & $\begin{array}{l}(-) \\
(7)\end{array}$ & & & \\
\hline \multirow[b]{2}{*}{$\mathrm{RM} 6$} & M & $\begin{array}{l}\text { E } 160 \\
\text { M } 640\end{array}$ & & & & & & & & & \multirow[b]{2}{*}{$\begin{array}{c}22, \mathrm{I} \\
{ }^{\prime} 52\end{array}$} & \multirow[b]{2}{*}{11} \\
\hline & $\mathrm{N}$ & $\begin{array}{c}\mathrm{E} 10 \\
\mathrm{M} 40 \\
(1,2)\end{array}$ & & & $\begin{array}{cc}\mathbf{E} & 10 \\
M & 80 \\
(3)\end{array}$ & $\left|\begin{array}{cc}\mathrm{E} & 10 \\
\mathrm{M} & 40 \\
(4)\end{array}\right|$ & $\begin{array}{cc}\mathrm{E} & 0 \\
\mathrm{M} & 40 \\
(3)\end{array}$ & $\left|\begin{array}{lr}\mathrm{E} & 0 \\
\mathrm{M} & 10 \\
(3,4)\end{array}\right|$ & $\begin{array}{c}(-) \\
(3,4)\end{array}$ & & & \\
\hline
\end{tabular}

(Wilmington strain) yolk sac emulsion was injected intraperitoneally into two mother rats before conception and two other rats during gestation. The C. F. antibodies in the newborns were followed up for several weeks. The antibodies were demonstrated soon after their birth reaching the highest level in the 1st and 2 nd week. Decreasing thereafter they became undemonstrable by the end of 6-7 weeks after birth.

As a control experiment, the C. F. antibodies in the newborns from 3 litters of normal mothers were tested and all proved negative (lower than 1:10).

Experiment 2. The cross-nursing experiments (Table 2):

i) The C. F. antibodies in the newborns delivered by immune mothers and nursed upon normal foster mothers (the placental transmission): The C. F. antibodies in the newborns of 3 litters were followed up. The antibodies were demonstrated soon after their birth, decreasing thereafter they became negative by the end of 3-4 weeks. 
Table 2

\begin{tabular}{|c|c|c|c|c|c|c|c|c|c|c|}
\hline \multicolumn{3}{|c|}{ Status of newborns } & \multicolumn{8}{|c|}{ C.F. titer in newborns } \\
\hline \multirow{2}{*}{$\begin{array}{l}\text { Born from } \\
\text { mother No. }\end{array}$} & \multirow{2}{*}{$\begin{array}{l}\text { Nursed by } \\
\text { mother No. }\end{array}$} & \multirow{2}{*}{\begin{tabular}{|} 
Days \\
after de- \\
livery to \\
nursing
\end{tabular}} & \multicolumn{8}{|c|}{ Weeks after birth to bleeding } \\
\hline & & & \begin{tabular}{|l} 
Imme- \\
diately
\end{tabular} & 1 & 2 & 3 & 4 & 5 & 6 & 7 \\
\hline $\begin{array}{cc}R \quad 7 \\
\text { (immune) }\end{array}$ & $\begin{array}{c}\mathrm{R} 11 \\
\text { (normal) }\end{array}$ & 0 & & & $\left|\begin{array}{ll}\text { E } & 20 \\
\text { M } & 40 \\
(7,8)\end{array}\right|$ & $\begin{array}{cc}\begin{array}{c}E \\
M\end{array} & 0 \\
(9)\end{array}$ & $\begin{array}{l}(-) \\
(10)\end{array}$ & & & \\
\hline $\begin{array}{c}R \quad 8 \\
\text { (immune) }\end{array}$ & $\mid \begin{array}{c}\mathrm{R} 16 \\
\text { (normal) }\end{array}$ & 0 & $\begin{array}{ll}\mathrm{E} & 20 \\
\mathrm{M} & 40 \\
(1, & 2)\end{array}$ & \begin{tabular}{|lr}
$\mathrm{E}$ & 0 \\
$\mathrm{M}$ & 20 \\
$(3,4)$
\end{tabular} & $\left|\begin{array}{cc}\mathrm{E} & 0 \\
\mathrm{M} & 10 \\
(5)\end{array}\right|$ & $\begin{array}{c}(-) \\
(6)\end{array}$ & & & & \\
\hline $\begin{array}{c}R 15 \\
\text { (immune) }\end{array}$ & $\mid \begin{array}{c}\mathrm{R} 19 \\
\text { (normal) }\end{array}$ & 0 & $\begin{array}{cc}\mathrm{E} & 10 \\
\mathrm{M} & 40 \\
(1, & 2)\end{array}$ & & $\left|\begin{array}{cc}\mathrm{E} & 10 \\
\mathrm{M} & 20 \\
(3)\end{array}\right|$ & $\begin{array}{c}(-) \\
(4)\end{array}$ & $\begin{array}{c}(-) \\
(4)\end{array}$ & & & \\
\hline $\begin{array}{c}\mathrm{R} 16 \\
\text { (normal) }\end{array}$ & $\begin{array}{cc}R & 8 \\
\text { (immune) }\end{array}$ & 0 & $\begin{array}{l}(-) \\
(1)\end{array}$ & $\begin{array}{ll}\text { E } 20 \\
\text { M } 40 \\
(3,4)\end{array}$ & & $\left|\begin{array}{cc}E & 20 \\
M & 40 \\
(5)\end{array}\right|$ & & & & \\
\hline $\begin{array}{c}\mathrm{R} 24 \\
\text { (normal) }\end{array}$ & $\begin{array}{c}\mathrm{RM} 6 \\
\text { (immune) }\end{array}$ & 15 & & & $\left|\begin{array}{cc}\mathbf{E} & 40 \\
\mathbf{M} & 80 \\
(1)\end{array}\right|$ & $\mid \begin{array}{cc}\mathrm{E} & 20 \\
\mathrm{M} & 40 \\
(2)\end{array}$ & $\begin{array}{cc}\mathbf{E} & 20 \\
\mathrm{M} & 80 \\
(1)\end{array}$ & \begin{tabular}{cc|}
$\mathbf{E}$ & 20 \\
M & 40 \\
(1)
\end{tabular} & \begin{tabular}{|cr}
$\mathrm{E}$ & 0 \\
$\mathrm{M} 20$ \\
$(1)$
\end{tabular} & $\begin{array}{l}(-) \\
(1)\end{array}$ \\
\hline $\begin{array}{c}\mathrm{R} 25 \\
\text { (normal) }\end{array}$ & $\begin{array}{c}\mathrm{RM} 6 \\
\text { (immune) }\end{array}$ & 21 & & $\mid \begin{array}{c}\text { E } 10 \\
\text { M } 20 \\
(2)\end{array}$ & $\left|\begin{array}{cc}\mathrm{E} & 40 \\
\mathrm{M} & 80 \\
(3)\end{array}\right|$ & $\begin{array}{ll}\mathrm{E} & 10 \\
\mathrm{M} & 80 \\
(3,4)\end{array}$ & $\left|\begin{array}{cc}E & 10 \\
M & 40 \\
(3)\end{array}\right|$ & & 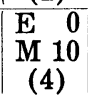 & $\begin{array}{l}(-) \\
(4)\end{array}$ \\
\hline
\end{tabular}

ii) The C. F. antibodies in the newborns from normal mothers and nursed upon immune foster mothers (the transmission by colostrum and milk): The newborns from normal mothers were nursed upon immune foster mothers. The nursing were started with colostrum, 15th day's milk and 21st day's milk of immune foster mothers. After one week of nursing, the C. F. antibodies in the newborns became demonstrable, and reached the highest level in the 2nd week. Decreasing thereafter the antibodies proved negative at the end of 7 weeks after birth.

Experiment 3. The C. F. antibodies in the newborns nursed by actively immunized mothers during their lactation (the transmission via colostrum and milk ) (Table 3): The C. F. antibodies were demonstrated to become positive in the sera of the newborns nursed by their own mothers actively immunized

Table 3

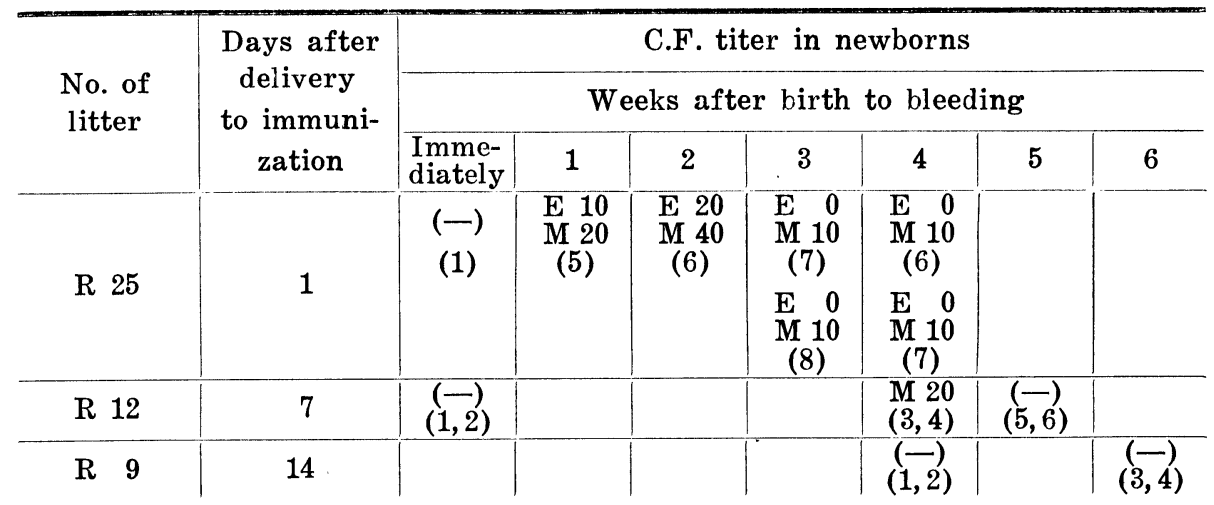


with live $R$. typhi 1 and 7 days after delivery, but negative in the newborns nursed by their own mothers immunized 14 days after delivery.

Experiment 4. The C. F. antibodies in newborns from the mothers actively immunized with commercial epidemic typhus vaccine (The transmission via colostrum and milk): The mother rats were injected with commercial epidemic typhus vaccine 11 times (dosis 2-5 cc) from one day before delivery till the 19th day after it. In the sera of newborns at the 19th and the 25th days, the C. F. antibodies were positive with the titre $\mathrm{E} 1: 40, \mathrm{M} 1: 10$ and E 1:20 M (-).

Experiment 5. The C. F. antibodies in newborns from the mothers passively immunized with rabbit specific anti-sera against epidemic and murine typhus (Table 4): Three mother rats were injected intraperitoneally with specific antisera for 4-6 successive days (daily dosis $5 \mathrm{cc}$ ). The injections of antisera were started during lactation in 2 rats and before delivery in the other rat.

Table 4

\begin{tabular}{|c|c|c|c|c|c|c|c|c|c|}
\hline & No. of litter & \multicolumn{3}{|c|}{ R 101} & \multicolumn{2}{|c|}{ R 103} & \multicolumn{3}{|c|}{ R 105} \\
\hline \multirow{7}{*}{$\begin{array}{l}\text { Mo- } \\
\text { ther }\end{array}$} & Date of delivery & \multicolumn{3}{|c|}{$10 / V^{\prime} 52$} & \multicolumn{2}{|c|}{ 171VI '52 } & \multicolumn{3}{|c|}{28 'VII '52 } \\
\hline & $\begin{array}{l}\text { Days after delivery } \\
\text { to immunization }\end{array}$ & \multicolumn{3}{|c|}{$3 \sim 7$} & \multicolumn{2}{|c|}{$8 \sim 11$} & \multicolumn{3}{|c|}{$-2 \sim 3$} \\
\hline & $\begin{array}{l}\text { Amount of antisera } \\
\text { injected }\end{array}$ & \multicolumn{3}{|c|}{$5 \mathrm{cc} \times 5$} & \multicolumn{2}{|c|}{$5 c c \times 4$} & \multicolumn{3}{|c|}{$5 c c \times 6$} \\
\hline & No. of antisera & \multicolumn{3}{|c|}{ K101 (rabbit) } & \multicolumn{2}{|c|}{ K104 (rabbit) } & \multicolumn{3}{|c|}{ K110 (rabbit) } \\
\hline & $\begin{array}{l}\text { C.F. titer of anti- } \\
\text { sera }\end{array}$ & \multicolumn{3}{|c|}{$\begin{array}{l}\text { E } 640 \\
\text { M } 160\end{array}$} & \multicolumn{2}{|c|}{$\begin{array}{l}\mathrm{E} \\
\mathrm{M}\end{array}$} & \multicolumn{3}{|c|}{$\begin{array}{lr}\mathrm{E} & 1280 \\
\mathrm{M} & 80\end{array}$} \\
\hline & $\begin{array}{l}\text { Days after delivery } \\
\text { to bleeding }\end{array}$ & \multicolumn{3}{|c|}{2} & 3 & 16 & -2 & \multicolumn{2}{|r|}{6} \\
\hline & C.F. titer of mother & $(-)$ & \multicolumn{2}{|c|}{$\begin{array}{l}\mathrm{E} \quad 160 \\
\mathrm{M} \quad 80 \\
\end{array}$} & $(一)$ & $\begin{array}{l}\mathrm{E} 160 \\
\mathrm{M} 40\end{array}$ & $(-)$ & & $\begin{array}{r}160 \\
40\end{array}$ \\
\hline \multirow{3}{*}{$\begin{array}{r}\text { New- } \\
\text { born }\end{array}$} & No. of newborns & 1,2 & 3,4 & 5,6 & 1,2 & 3,4 & $1,2,3$ & 4,5 & 6 \\
\hline & $\begin{array}{l}\text { Days after birth to } \\
\text { bleeding }\end{array}$ & 2 & 10 & 10 & 3 & 13 & 1 & 4 & 6 \\
\hline & $\begin{array}{l}\text { C.F. titer of new- } \\
\text { borns }\end{array}$ & $(-)$ & \begin{tabular}{|lr}
$\mathrm{E}$ & 10 \\
$\mathrm{M}$ & 0
\end{tabular} & \begin{tabular}{ll|} 
E & 20 \\
M & 10
\end{tabular} & $(-)$ & $\begin{array}{l}\mathrm{E} 10 \\
\mathrm{M}\end{array}$ & $(-)$ & $\begin{array}{ll}\mathrm{E} & 40 \\
\mathrm{M} & 10\end{array}$ & $\begin{array}{ll}\mathrm{E} & 40 \\
\mathrm{M} & 0\end{array}$ \\
\hline
\end{tabular}

The C. F. antibodies were negative before immunization and became positive after immunization in both mothers and newborns.

B. Results obtained in guinea pigs.

Preliminaly experiment: The abortion found in guinea pigs inoculated with live $R$. prowazeki during gestation.

Abortion has occurred in 4 out of 5 pregnant guinea pigs when injected 1 cc of $5 \% R$. prowazeki yolk sac emulsion intraperitoneally, just as pregnant guinea pigs infected with typhus are often found to miscarry during the febrile stage. Besides, isolation of the rickettsiae from the aborted foetus has proved negative. From above results, immunization of the mother guinea pigs during gestation has been carried out with killed rickettsial vaccine. 
Experiment 1. The C. F. antibodies in the newborns from immunized mothers and nursed by the same mothers.

i) When mothers have been actively immunized with live rickettsiae:

Two guinea pigs were injected with $R$. prowazeki yolk sac emulsion 62 and 75 days before delivery respectively and another one with $R$. typhi yolk sac emulsion 80 days before delivery. The C. F. antibodies in the newborns from these mothers became positive soon after birth and lasted for $2-3$ weeks. The C. F. titres of mothers, were the same or a slightly higher than those of the newborns at the time of delivery. Concerning the specificity of C. F. antibodies against $\mathrm{E}$ and $\mathrm{M}$ antigens, some cross reactions were found provable but C. F. titres in the newborns were higher against homologous antigen than against heterologous antigen (Table 5).

Table 5

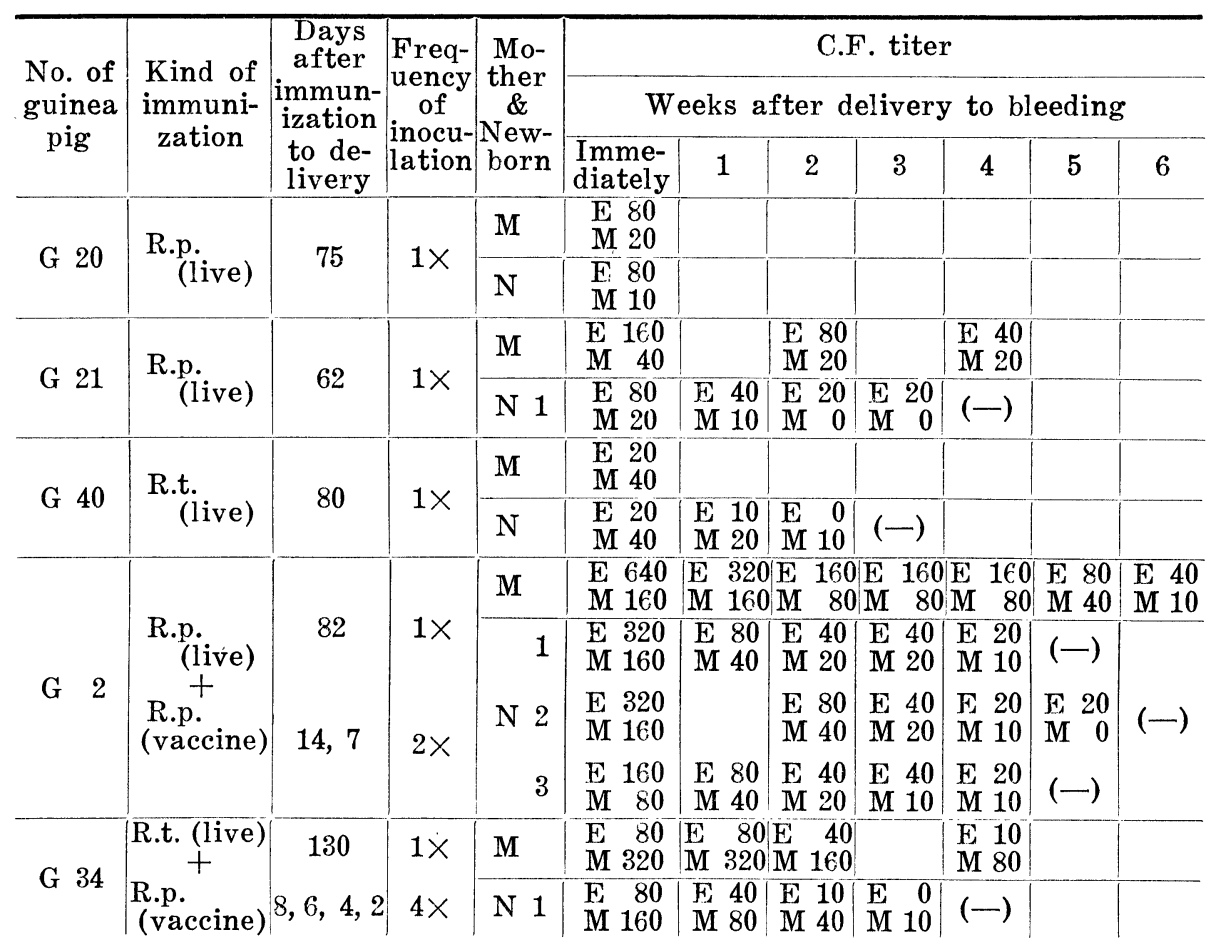

ii) When mothers were actively immunized with live rickettsiae and killed rickettsial vaccine:

Guinea pig G2 was injected with $R$. prowazeki yolk sac emulsion febore pregnancy and two boosters of $R$. prowazeki Vaccine 1 and 2 weeks before delivery. The C. F. antibodies in the 3 newborns were followed up successively for several weeks. They demonstrated the highest titers soon after their birth, however, they were slightly lower than their mothers', and gradually 
decreased thereafter becoming negative by the end of 5-6 weeks after birth (Table 5).

Guinea pig G34 was injected with $R$. typhi yolk sac emulsion before conception and with 4 boosters of $R$. prowazeki vaccine prior to delivery. The C. F. antibodies in the newborns demonstrated a titre slightly lower than that in mothers and proved negative 4 weeks after birth. One of the two newborns was nursed by normal foster mothers. In spite of booster injection of $R$. prowazeki the $\mathrm{C}$. $\mathrm{F}$. antibodies against $\mathrm{M}$ antigen have shown to be higher than those against $\mathrm{E}$ antigen, as a paradoxical reaction, according to anamnesis (Table 5, Table 7).

iii) When mothers were actively immunized with killed rickettsial vaccine (Table 6): When immunization was started at the end of pregnancy, the

Table 6

\begin{tabular}{|c|c|c|c|c|c|c|}
\hline \multirow{2}{*}{$\begin{array}{l}\text { No. of } \\
\text { guinea } \\
\text { pig }\end{array}$} & \multirow{2}{*}{$\begin{array}{l}\text { Kind of } \\
\text { immuniza- } \\
\text { tion }\end{array}$} & \multirow{2}{*}{$\begin{array}{c}\text { Days after } \\
\text { immuniza- } \\
\text { tion to } \\
\text { delivery }\end{array}$} & \multirow{2}{*}{$\begin{array}{c}\text { Frequ- } \\
\text { ency of } \\
\text { inocula- } \\
\text { tion }\end{array}$} & \multirow{2}{*}{$\begin{array}{c}\text { Mother } \\
\& \\
\text { Newborn }\end{array}$} & \multicolumn{2}{|c|}{ C.F. titer } \\
\hline & & & & & $\begin{array}{c}\text { Soon after } \\
\text { deiivery }\end{array}$ & $\begin{array}{c}1 \text { week } \\
\text { after del. }\end{array}$ \\
\hline \multirow{2}{*}{ G 317} & \multirow{2}{*}{$\begin{array}{l}\text { R.p. } \\
\text { (vaccine) }\end{array}$} & \multirow{2}{*}{4,2} & \multirow{2}{*}{$2 \times$} & M & $(-)$ & $\mathrm{E} 40, \mathrm{M} 0$ \\
\hline & & & & $\mathrm{N}$ & $(-)$ & $(-)$ \\
\hline \multirow{2}{*}{ G 316} & \multirow[b]{2}{*}{$"$} & \multirow{2}{*}{5,2} & \multirow{2}{*}{$2 \times$} & M & $(-)$ & $\mathrm{E} 20, \mathrm{M} 0$ \\
\hline & & & & $\mathrm{N}$ & $(-)$ & $(-)$ \\
\hline \multirow{2}{*}{ G 306} & \multirow[b]{2}{*}{ 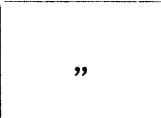 } & \multirow{2}{*}{$10,8,6,2$, } & \multirow{2}{*}{$4 \times$} & $M$ & E $40, \mathrm{M} 0$ & E $160, \mathrm{M} 40$ \\
\hline & & & & $\mathrm{N}$ & $(-)$ & $(-)$ \\
\hline \multirow{2}{*}{ G 315} & \multirow[b]{2}{*}{$"$} & \multirow{2}{*}{$\begin{array}{c}18,16,14,12, \\
10\end{array}$} & \multirow{2}{*}{$5 \times$} & M & $\mathrm{E} 20, \mathrm{M} 0$ & $\mathrm{E} 40, \mathrm{M} 0$ \\
\hline & & & & $\mathrm{N}$ & $($ (一) & $(-)$ \\
\hline \multirow[b]{2}{*}{ G 319} & \multirow[b]{2}{*}{$"$} & \multirow{2}{*}{$\begin{array}{c}35,33,31,29 \\
27\end{array}$} & \multirow[b]{2}{*}{$5 \times$} & M & $\mathrm{E} 80, \mathrm{M} 40$ & \\
\hline & & & & $\mathrm{N}_{2}^{1}$ & $\begin{array}{llll}\mathrm{E} & 40, & \mathrm{M} & 20 \\
\mathrm{E} & 40, & \mathrm{M} & 10\end{array}$ & \\
\hline G 207 & " & $55,50,45$ & $3 \times$ & $\begin{array}{l}\mathrm{M} \\
\mathrm{N}\end{array}$ & $\begin{array}{c}(-) \\
\mathrm{E} 10, \mathrm{M} 0\end{array}$ & $\begin{array}{l}(-) \\
(-)\end{array}$ \\
\hline G 305 & " & $\begin{array}{c}120,13 \\
8,3\end{array}$ & $\begin{array}{l}2 \times \\
2 \times\end{array}$ & $\begin{array}{l}\mathrm{M} \\
\mathrm{N}\end{array}$ & $\begin{array}{l}\text { E } 160, \text { M } 40 \\
\text { E } 10, \text { M } 0\end{array}$ & $\begin{array}{c}\mathrm{E} 80, \mathrm{M} 20 \\
(-)\end{array}$ \\
\hline
\end{tabular}

C. F. antibodies were negative in both mothers and newborns at the time of delivery and only that of mother became positive 1 week later. If the immunization was started in the middle stadium of gestation, the C. F. antibodies were found developing in both mothers and newborns, and the titre in mothers were found a little higher than those of new borns.

In one instance, however, the immunization was started from the beginning of delivery and the C. F. antibodies was demonstrated only in new borns. 
In another instance, which was immunized before delivery and a booster injection was given 8 days before delivery, the C. F. antibodies were demonstrated in both mother and newborns. The titre in mother was much higher than that of newborns $(1: 160$ to $1: 10)$.

Table 7

\begin{tabular}{|c|c|c|c|c|c|c|c|}
\hline \multirow{3}{*}{$\begin{array}{c}\text { No. of } \\
\text { guinea pig }\end{array}$} & \multicolumn{2}{|c|}{ Status of newborns } & \multirow{2}{*}{\multicolumn{5}{|c|}{$\begin{array}{l}\text { C.F. titer in newborns } \\
\text { Weeks after birth to bleeding }\end{array}$}} \\
\hline & \multirow{2}{*}{$\begin{array}{c}\text { Born from } \\
\text { mother } \\
\text { No. }\end{array}$} & \multirow{2}{*}{\begin{tabular}{|c} 
Nursed by \\
mother \\
No.
\end{tabular}} & & & & & \\
\hline & & & \begin{tabular}{|l|} 
Imme- \\
diately
\end{tabular} & 1 & 2 & 3 & 3 \\
\hline G $21-2$ & $\underset{\text { (immune) }}{\mathrm{G} \mathrm{21}}$ & $\underset{\text { (normal) }}{\mathrm{G} 28}$ & $\begin{array}{l}\text { E } 80 \\
\text { M } 20\end{array}$ & $\begin{array}{lr}\mathrm{E} & 40 \\
\mathrm{M} & 0\end{array}$ & $\begin{array}{l}\mathrm{E} 20 \\
\mathrm{M} \quad 0\end{array}$ & $\begin{array}{l}\mathrm{E} 10 \\
\mathrm{M} \quad 0\end{array}$ & $(-)$ \\
\hline G $34-2$ & $\begin{array}{c}\text { G 34 } \\
\text { (immune) }\end{array}$ & $\begin{array}{c}\text { G 107 } \\
\text { (normal) }\end{array}$ & $\begin{array}{lr}\mathrm{E} & 80 \\
\mathrm{M} & 160 \\
\end{array}$ & $\begin{array}{ll}\mathrm{E} & 10 \\
\mathrm{M} & 40\end{array}$ & $\begin{array}{ll}\mathrm{E} & 10 \\
\mathrm{M} & 40\end{array}$ & $\begin{array}{lr}\mathrm{E} & 0 \\
\mathrm{M} & 10 \\
\end{array}$ & $(-)$ \\
\hline G $28-1$ & $\begin{array}{c}\text { G } 28 \\
\text { (normal) }\end{array}$ & $\begin{array}{c}\mathrm{G} 21 \\
\text { (immune) }\end{array}$ & $(-)$ & $(-)$ & $(-)$ & & \\
\hline G $29-1$ & $\begin{array}{c}\text { G } 29 \\
\text { (normal) }\end{array}$ & $\begin{array}{c}\mathrm{G} 21 \\
\text { (immune) }\end{array}$ & $(-)$ & $(-)$ & & & \\
\hline G $107-1$ & $\begin{array}{c}\text { G } 107 \\
\text { (normal) }\end{array}$ & $\underset{\text { (immune) }}{\mathrm{G} 34}$ & $(-)$ & $(-)$ & $(-)$ & & \\
\hline
\end{tabular}

Experiment 2. The cross-nursing experiments (Table 7):

i) The C. F. antibodies in the newborns from immune mothers and nursed by normal foster mothers: One newborn (G 21-2) from th emother immunized with epidemic typhus and another newborn (G 34-2) from the mother immunized with murine typhus were nursed by normal foster mother respectively. The fluctuation of C. F. antibodies observed in these two newborns was much the same as in those nursed by their own mothers (G 21-1, and G 34-1) (Table 5).

The C. F. antibodies in the newborns decreased gradually after birth and became negative in 4 weeks' time.

ii) The C. F. antibodies in the newborns from normal mothers and nursed by immune foster mothers: Three newborns from normal mothers were nursed by immune foster mothers. The C. F. antibodies were not demonstrated in the newborns after 1 and 2 weeks' nursing by immune foster mothers.

Experiment 3. The C. F. antibodies in the foetus of the mothers passively immunized during gestation: Two guinea pigs were injected with specific homologous (guinea pig) immune sera against typhus, and another one with heterologous (rabbit) immune sera against typhus. The condition of immunization was as shown in Table 8. After passive immunization, the foetus was taken out by laparotomy and the blood of foetus was collected by cardial pancture. Amniotic fluid was collected, at the same time, paying much care not to mix mother's blood. The C. F. antibodies were found positive in the foetus. 
Table 8

\begin{tabular}{|c|c|c|c|c|c|c|c|}
\hline $\begin{array}{l}\text { Mother } \\
\& \\
\text { Foetus }\end{array}$ & No. of guinea pig & \multicolumn{2}{|c|}{ G 325} & \multicolumn{2}{|c|}{ G 332} & \multicolumn{2}{|c|}{ G 333} \\
\hline \multirow{7}{*}{ Mother } & Body weight & \multicolumn{2}{|c|}{$765 \mathrm{~g}$} & \multicolumn{2}{|c|}{$655 \mathrm{~g}$} & \multicolumn{2}{|c|}{$595 \mathrm{~g}$} \\
\hline & Date of immunization & \multicolumn{2}{|c|}{$\begin{array}{l}\text { 4/VII 10/VII } \\
\text { '52 }\end{array}$} & \multicolumn{2}{|c|}{$\begin{array}{l}31 / \text { VII } \sim 6 / \text { VIII } \\
{ }^{52}\end{array}$} & \multicolumn{2}{|c|}{$\begin{array}{l}4 / \mathrm{VIII} \sim 9 / \mathrm{VIII} \\
/ 52\end{array}$} \\
\hline & $\begin{array}{l}\text { Amount of antisera } \\
\text { injected }\end{array}$ & \multicolumn{2}{|c|}{$5 \mathrm{cc} \times 7$} & \multicolumn{2}{|c|}{$5 \mathrm{cc} \times 7$} & \multicolumn{2}{|c|}{$5 \operatorname{cc} \times 6$} \\
\hline & No. of antisera & \multicolumn{2}{|c|}{ G-T-1 (g.p.) } & \multicolumn{2}{|c|}{ K 106 (rabbit) } & \multicolumn{2}{|c|}{ G-T-2 (g.p.) } \\
\hline & C.F. titer of antisera & \multicolumn{2}{|c|}{ E 320, M 320} & \multicolumn{2}{|c|}{ E 1280, M 80} & \multicolumn{2}{|c|}{ E 320, M 320} \\
\hline & Date of bleeding & $8 /$ VII & $11 ; \mathrm{VII}$ & $31 / \mathrm{VII}$ & 7/VIII & 4/VIII & $10 /$ VIII \\
\hline & C.F. titer & $(-)$ & $\begin{array}{l}\mathrm{E} 160 \\
\mathrm{M} 160\end{array}$ & $(-)$ & $\begin{array}{l}\text { E } 80 \\
\text { M } 10 \\
\end{array}$ & $(一)$ & $\begin{array}{l}\mathrm{E} 40 \\
\mathrm{M} 10\end{array}$ \\
\hline \multirow{5}{*}{ Foetus } & No. of foetus & 1 & 2 & 1 & 2 & 1 & 2 \\
\hline & Body weight & $25 \mathrm{~g}$ & $24 \mathrm{~g}$ & $37 \mathrm{~g}$ & $\begin{array}{c}8 \mathrm{~g} \\
\text { (dead) }\end{array}$ & $46 \mathrm{~g}$ & $35 \mathrm{~g}$ \\
\hline & Weight of placenta & $5 \mathrm{~g}$ & $4 \mathrm{~g}$ & $4.5 \mathrm{~g}$ & 一 & $4.5 \mathrm{~g}$ & $3.5 \mathrm{~g}$ \\
\hline & Date of bleeding & \multicolumn{2}{|l|}{$11 / \mathrm{VII}$} & $7 /$ VIII & 一 & $10 / \mathrm{VIII}$ & $"$ \\
\hline & C.F. titer & \multicolumn{2}{|c|}{$\mathrm{E} 40, \mathrm{M} 40$} & \multicolumn{2}{|c|}{$\mathrm{E} 10, \mathrm{M} 0$} & $\begin{array}{l}\mathrm{E} \\
\mathrm{M}\end{array}$ & $\begin{array}{lr}\mathrm{E} & 10 \\
\mathrm{M} & 0\end{array}$ \\
\hline \multirow{2}{*}{$\begin{array}{l}\text { Amniotic } \\
\text { fluid }\end{array}$} & Amount & \multicolumn{2}{|c|}{$4.0 \mathrm{cc}$} & \multicolumn{2}{|c|}{$2.0 \mathrm{cc}$} & \multicolumn{2}{|c|}{$2.0 \mathrm{cc}$} \\
\hline & C.F. titer & \multicolumn{2}{|c|}{$(-)$} & \multicolumn{2}{|c|}{$(-)$} & \multicolumn{2}{|c|}{$(-)$} \\
\hline
\end{tabular}

Table 9

\begin{tabular}{|c|c|c|c|c|c|}
\hline $\begin{array}{c}\text { Mother } \\
\& \\
\text { Foetus }\end{array}$ & No. of guinea pig & \multicolumn{2}{|c|}{ G 320} & \multicolumn{2}{|c|}{ G 210} \\
\hline \multirow{4}{*}{ Mother } & Body weight & \multicolumn{2}{|c|}{$645 \mathrm{~g}$} & \multicolumn{2}{|c|}{$710 \mathrm{~g}$} \\
\hline & Immunization & \multicolumn{2}{|c|}{$\begin{array}{l}\text { 19/I '52 (before preg.) } \\
\text { R.t. (live) } \\
\text { 2/VI, 9/VI(during gest.) } \\
\text { R.p. (vaccine) } 1 \text { cc } \times 2\end{array}$} & \multicolumn{2}{|c|}{$\begin{array}{l}\text { 17/I '52 (before preg.) } \\
\text { R.t. (live) } \\
\text { 11/VII, 18/VII, 25/VII } \\
\text { (during gest.) } \\
\text { R.p. (vaccine) } 1 c c \times 3\end{array}$} \\
\hline & Date of bleeding & \multicolumn{2}{|c|}{$14 / \mathrm{VI} ' 52$} & \multicolumn{2}{|c|}{ 29/VII '52 } \\
\hline & C.F. titer & \multicolumn{2}{|c|}{ E 640, M 640} & \multicolumn{2}{|c|}{ E $160, M 160$} \\
\hline \multirow{5}{*}{ Foetus } & No. of foetus & 1 & 2 & 1 & 2 \\
\hline & Body weight & $12 \mathrm{~g}$ & $2 \mathrm{~g}($ dead $)$ & $75 \mathrm{~g}$ & $73 \mathrm{~g}$ \\
\hline & Weight of placenta & $3 \mathrm{~g}$ & 一 & $5.5 \mathrm{~g}$ & $5.5 \mathrm{~g}$ \\
\hline & Date of bleeding & $14 / \mathrm{VI}$ & - & $29 / \mathrm{VII}$ & " \\
\hline & C.F. titer & $\begin{array}{l}\mathrm{E} 160 \\
\mathrm{M} \quad 80\end{array}$ & - & \multicolumn{2}{|c|}{ E 160, M 160} \\
\hline \multirow{2}{*}{$\begin{array}{l}\text { Amniotic } \\
\text { fluid }\end{array}$} & Amount & \multicolumn{2}{|c|}{$4 \mathrm{cc}$} & \multicolumn{2}{|c|}{$5 \mathrm{cc}$} \\
\hline & C.F. titer & \multicolumn{2}{|c|}{ E $1: 2$, M $1: 2$} & \multicolumn{2}{|c|}{$(-)$} \\
\hline
\end{tabular}


The C. F. antibodies found in the foetus of the mother immunized with homologous anti-sera seemed to be a little higher than those found in the foetus of the mother immunized with heterologous antisera. The C. F. antibodies in amniotic fluid were not demonstrated.

Experiment 4. Demonstration of C. F. antibodies in amniotic fluid: The C. F. antibodies in the amniotic fluid were not demonstrated in the above experiments, but the C. F. antibodies were positive in the amniotic fluid of a guinea pig strongly immunized with live and killed rickettsiae before and during gestation. The C. F. titres in the mother, foetus and amniotic fluid were 1:640, $1: 160,1: 2$ against $\mathrm{E}$ antigen respectively (Table 9)

\section{Discussion}

Two main routes through which the maternal antibodies may be transferred to the offsprings are considered to be via placenta and via colostrum and milk. The relation between the structure of placenta and placental transmission of antibodies have been studied precisely since Grosser. The smaller the number of cell layers which separate the maternal circulation from that of foetus the antibodies pass the more easily through placenta. For instance, in human, monkey, rabbit, mouse, rat etc. having haemochorial type of placenta of one cell layer, the antibodies are transmitted mainly via placenta while, in ox, sheep, goat and other ruminants having the syndesmochorial type of placenta of 3-4 cell layers, the route of transmission is considered chiefiy via colostrum and milk.

Exceptionally in rats and mice, which belong to hemochorial type, their antibodies were demonstrated to be transfered not only via placenta but also via colostrum and milk.13),14),15)

Experiments were also carried out to determine the route through which the C. F. antibodies of typhus fever are transmitted from the mother to the offsprings in rats and guinea pigs.

During the course of the experiment, Worth ${ }^{16)}$ published the data that the murine typhus C. F. antibodies can be transferred from the mother to the newborn in roof rats and cotton rats caught in field, which coincides with the results in albino rats observed by the author. The crossnursing experiments were performed, further, to analyse the route of passage. In the experiment of albino rats, C. F. antibodies were demonstrated to be transmitted from the mother to the offsprings not only via placenta but also via colostrum and milk. In guinea pigs, however, the transmission via colostrum and milk was not demonstrated.

It must be attributed to certain special conditions of newborn guinea pigs, such as the long period of gestation, the perfect formation of body at the time of birth and the short and undeterminable period of lactation. 
Direct demonstration of C. F. antibodies in the milk was not yet attempted because of the difficulty to acquire a sufficient quantity of the specimen.

In the above experiment, when active immunization was carried out during gestation and lactation, the transfer of rickettsiae themselves and soluble antigen via placenta and via colostrum must be taken into consideration. Though the passing of rickettsiae themselves to the foetus or the newborn was denied by our experiment (unpublished data), that of soluble antigen remains still as a question.

Demonstration of C. F. antibodies in the amniotic fluid of a strongly immunized pregnant guinea pig was successful.

It is not clear whether the C. F. antibodies pass into the amniotic fluid from the mother or the foetus. If the C. F. antibodies in the maternal circulation would pass directly into the amniotic cavity, it may be allowed to consider, as Calman ${ }^{14)}$ pointed out, that the foetus would drink the antibodies and concentrate them in their stomach as ruminants do after birth. The admission of antibodies to foetus via yolk sac splanchnopleure in rabbits was confirmed by Brambell17). Intra-uterine transmission of antibodies to foetus other than across the placenta would require further investigation.

\section{SUMMARY AND CONCLUSION}

(1) When mother rats were actively immunized with live $R$. typhi prior to gestation, during gestation and lactation, with killed $R$. Prowazeki vaccine during lactation or passively immunized with specific rabbit antisera during lactation, the C. F. antibodies were proved developing in the sera of newborns.

(2) In the above experiments and cross-nursing experiments of immune and normal mothers, the maternal C. F. antibodies in rats were demonstrated to be transmitted to their offsprings not only via placenta but also via colostrum and milk.

(3) When mother guinea pigs were actively immunized with live $R$. prowazeki and $R$. typhi and killed $R$. prowazeki vaccine, before and during gestation or passively immunized with specific homologous (guinea pig) or heterologous (rabbit) antisera during gestation, the C. F. antibodies were demonstrated in the newborns or in the foetus.

(4) In the above experiments and cross-nursing experiments the C. F. antibodies in guinea pigs were proved to be transmitted to their offsprings mainly through placenta and not via colostrum and milk.

(5) The newborns were bled for several successive weeks and the fluctuation of C. F. antibodies transmitted from mothers to their newborns was analysed.

The author would like to thank Dr. M. kitaoka for his constant interest and advise. 


\section{REFERENCES}

1) Rickard, E. R. and Horsefall, F. L.: J. Immunol., 42, 262-272, 1941.

2) Tsurumi, S.: The report of the research committee with the research fund of Educational Department, 1950. (in Japanese)

3) Segawa, K.: Jika Zasshi, 45, 1519-1538, 1939. (in Japanese)

4) Mitamura, T. Hazato, H. Watanabe, Z. Okubo, K., Ichikawa, O. and Tenjin, S.: Tokyo Iji Shinshi, No. 3076, 804-809, 1938. (in Japanese)

5) Kitaoka, M. and Miura, T.: Igaku to Seibutsugaku, 17, 171-173, 1950. (in Japanese)

6) Aycock, W. L. and Kramer, S. D.: J. Exper. Med., 52, 457-464, 1930.

7) Kitaoka, M. and Miura, T.: Japanese Med. J., 2, 285-294, 1949; 4, 297-305, 1951.

8) Soper, F. L.;Beeuwkes, H. Davis, N. and Kerr, J. A.: Amer. J. Hyg., 27, 351-363, 1938.

9) Melnick, J. L. and Clarke, N. A.: J. Exper. Med., 92, 499-505, 1950.

10) Levine, S., Bullowa, J. G. M. and Scheinblum, I. E.: J. Immunol., 47, 439-442, 1943.

11) Young, G. A. and Underdahl, N. R.: J. Immunol., 65, 369-373, 1950.

12) Plotz H., Bennett B. L., Wertman K. Snyder M. J. and Gauld R. L.: Amer. J. Hyg. 47, 150-165, 1948.

13) Perla, D. and Marmorston, J.: Natural resistance and Clinical Medicine, Boston, 1941.

14) Calman, R. M. and Murray, J.: Endeavour, 10, 27-32, 1951.

15) Parish, H. J.: Brit. Med. J. i, 1164-1168, 1951.

16) Worth, C. B.: Amer. J. Trop. Med. 31, 299-300, 1951.

17) Brambell, F. W. R., Hemming W. A., Henderson, M. and Rowlands, W. T.: Proc. Roy. Soc. B. 137, 239-252, 1950. 